\title{
The effect of dietary humic substances on the fattening performance, carcass yield, blood biochemistry parameters and bone mineral profile of broiler chickens
}

\author{
Iveta Jad’uttová ${ }^{1}$, Dana Marcinčáková ${ }^{2}$, Martin Bartkovský ${ }^{1}$, Boris Semjon ${ }^{1}$, \\ Michaela Harčárová ${ }^{2}$, Alena Nagyová ${ }^{3}$, Peter Váczi ${ }^{2}$, Slavomír Marcinčák ${ }^{1}$
}

University of Veterinary Medicine and Pharmacy in Košice, ${ }^{1}$ Department of Food Hygiene and Technology, ${ }^{2}$ Department of Pharmacology and Toxicology, ${ }^{3}$ Department of the Environment, Veterinary Legislation and Economy, Košice, Slovak Republic

Received March 15, 2019

Accepted June 13, 2019

\begin{abstract}
Humic substances are currently being considered as a new feed component in replacement of antibiotic growth stimulators to improve growth and health in animals. The aim of our work was to evaluate the effect of the addition of humic substances to the feed at concentrations of $0.8 \%$ and $1.0 \%$ on the growth parameters, carcass yield, selected blood enzymes, minerals, and the bone quality in broiler chickens. One hundred fifty COBB 500 one-day-old male broiler chicks were randomly divided into one control and two experimental groups $(\mathrm{n}=50)$ with three replications (16, 16 and 17 per pen), and fattened for 35 days. The broilers of the experimental groups (H0.8 and H1.0) were fed commercial feed mixtures with added humic substances (at $8 \mathrm{~g} \cdot \mathrm{kg}^{-1}$ and $10 \mathrm{~g} \cdot \mathrm{kg}^{-1}$ ). The control group was fed a diet without the addition of humic substances. A slight increase in the final body weight and feed conversion ratio was noted in the experimental groups $(P>0.05)$. Significantly higher yields of breast and thigh meat $(P<0.05)$ were recorded for the experimental group H1.0. The blood cholesterol level was lower for both experimental groups. A lower concentration of alkaline-phosphatase was observed in group H1.0. A decrease in aspartate aminotransferase and calcium was recorded for group H0.8. A significantly higher content of calcium and lower content of phosphorus was found in the bones of experimental animals. The $1 \%$ addition of humic substances had a positive impact on growth parameters $(P>0.05)$, improved selected blood indices and increased the calcium content in the bones of broilers $(P<0.05)$.
\end{abstract}

Humic acid, production indicator, quality of bones

The most important factors that affect the efficacy of poultry production are the performance and disease control. Humic substances (HS) are natural compounds that have been used in agriculture for many years due to their positive impact and nutritional benefits for domestic animals. They include humus, humic acid, fulvic acid, and ulmic acid. Such substances have the potential to stimulate growth by improving the micronutrient intake (Y1ldiz et al. 2013). Humic substances have immuno-stimulatory, anti-inflammatory and anti-viral properties due to their ability to form a protective film on the mucosal epithelia of the intestine against infections and toxins (Bahadori et al. 2017). They have demonstrated a strong affinity to bind various substances, such as heavy metals, mycotoxins, and herbicides (Arafat et al. 2017). Including this natural component in the animal diet has been found to positively affect the functions of the immune system (Salah et al. 2015), improve gut health (Arif et al. 2018), reduce the incidence of diarrhoea and other digestive disorders, as well as to decrease mortality and maintain the standard health status (Nagaraju et al. 2014; Khan and Iqbal 2016). They influence the permeability of the cell wall and facilitate the transfer of minerals from blood to bone and cells (Y1ldiz et al. 2013). The absorption of mineral components that are important for the organism, e.g. calcium and phosphorus, is increased and enters the composition of tissues and body

Address for correspondence:

Slavomír Marcinčák

Department of Food Hygiene and Technology

University of Veterinary Medicine and Pharmacy in Košice

Komenského 73, 04181 Košice, Slovak Republic

Phone: +421915984756

E-mail: slavomir.marcincak@uvlf.sk

http://actavet.vfu.cz/ 
fluids, fulfilling a body-building function (Rath et al. 2006). Moreover, HS are also advantageous as they are non-toxic, non-teratogenic, and no withdrawal periods are needed (Ozturk et al. 2012; Arif et al. 2018).

There are many studies focused on the effect of the addition of HS to the feed during the fattening period, but the results are controversial. Some researchers reported a significant effect on the broilers' live weight, weight gain, carcass yield and feed conversion ratio (Karaoglu et al. 2004; Pistová et al. 2016). In contrast, many other studies noted only non-significant effects on the above-mentioned parameters during the fattening period (Ozturk et al. 2012; Y1ld1z et al. 2013; Nagaraju et al. 2014).

The aim of this work was evaluate the effect of HS added to the feed at different concentrations $(0.8 \%$ and $1.0 \%)$ on the production indicators of broiler chickens, mineral profile of bones (calcium and phosphorus) and on the changes in selected blood parameters.

\section{Materials and Methods}

The protocol for animal fattening was approved by the Ethics Committee for Animal Care and Use of the University of Veterinary Medicine and Pharmacy in Košice (with the consent of the State Veterinary and Food Administration of the Slovak Republic under number 3040/14-221). The experiment was carried out on the premises of the Clinic for Birds and Exotic Animals of the said university.

This study was conducted using 150 one-day-old male COBB 500 chicks (Gallus gallus domesticus) purchased from a commercial supplier (Mach Hydina Budmerice, Hydina Slovensko s.r.o., Slovak Republic). The chicks were randomly divided into 3 groups: one control (C) and two experimental groups (H0.8 and H1.0), 50 pieces per group. The chicks were reared on a deep litter in controlled conditions in agreement with the technological instructions for COBB 500 Broiler Management Guide (2013). There was a 24-h light regime on the first day of fattening which was gradually decreased to $18 \mathrm{~h}$ of light and $6 \mathrm{~h}$ of dark. The access to water and feed was

Table 1. Composition of broiler diets.

\begin{tabular}{lcccc}
\hline Ingredient & & BR1 & BR2 & BR3 \\
\hline Dry matter & $\mathrm{g} / \mathrm{kg}$ & 1000.00 & 1000.00 & 1000.00 \\
$\mathrm{CP}$ & $\mathrm{g} / \mathrm{kg}$ & 228.50 & 195.10 & 188.30 \\
Fat & $\mathrm{g} / \mathrm{kg}$ & 48.90 & 48.30 & 47.30 \\
Dietary fibre & $\mathrm{g} / \mathrm{kg}$ & 30.90 & 37.50 & 44.00 \\
$\mathrm{NDF}$ & $\mathrm{g} / \mathrm{kg}$ & 122.4 & 128.9 & 120.7 \\
$\mathrm{ADF}$ & $\mathrm{g} / \mathrm{kg}$ & 54.2 & 54.6 & 70.7 \\
Starch & $\mathrm{g} / \mathrm{kg}$ & 432.50 & 467.80 & 502.60 \\
Ash & $\mathrm{g} / \mathrm{kg}$ & 57.80 & 49.40 & 39.10 \\
$\mathrm{Ca}$ & $\mathrm{g} / \mathrm{kg}$ & 10.43 & 9.85 & 9.34 \\
$\mathrm{Mg}$ & $\mathrm{g} / \mathrm{kg}$ & 1.14 & 1.01 & 1.12 \\
$\mathrm{Na}$ & $\mathrm{g} / \mathrm{kg}$ & 1.55 & 1.68 & 1.37 \\
$\mathrm{~K}$ & $\mathrm{~g} / \mathrm{kg}$ & 8.86 & 7.16 & 6.82 \\
$\mathrm{P}$ & $\mathrm{g} / \mathrm{kg}$ & 5.88 & 6.04 & 5.36 \\
$\mathrm{Cu}$ & $\mathrm{mg} / \mathrm{kg}$ & 18.07 & 11.41 & 13.30 \\
$\mathrm{Zn}$ & $\mathrm{mg} / \mathrm{kg}$ & 120.27 & 99.35 & 109.19 \\
$\mathrm{Mn}$ & $\mathrm{mg} / \mathrm{kg}$ & 102.32 & 108.19 & 96.00 \\
$\mathrm{ME}$ & $\mathrm{MJ} / \mathrm{kg}$ & 13.10 & 13.00 & 13.30 \\
\hline
\end{tabular}

$\mathrm{CP}$ - crude protein, NDF - neutral detergent fibre, ADF - acid detergent fibre, ME - metabolisable energy, $\mathrm{Ca}$ - calcium, $\mathrm{Mg}$ - magnesium, $\mathrm{Na}$ - sodium, $\mathrm{K}$ - kalium, $\mathrm{Cu}$ - cuprum, $\mathrm{Zn}$ - zinc, $\mathrm{Mn}$ - manganese, $\mathrm{BR} 1$ - starter diet, BR2 - grower diet, BR3 - finisher diet 
ad libitum. The following commercial feed mixtures were used for fattening: BR1 - starter diet during the first 10 days of fattening; BR2 - grower diet from day 11 to day 28; BR3 - finisher diet from day 29 to day 35 (DeHeus, Bučovice, Czech Republic) (Table 1). The main components of the feed mixtures were wheat, corn, soybean meal, rapeseed cake and sunflower meal, animal fat, calcium carbonate, and sodium chloride. The experimental group diets were supplemented with natural HS (HUMAC ${ }^{\circledR}$ Natur AFM; Humac s.r.o., Slovak Republic) (Table 2 ) at the amount $0.8 \%$ and $1.0 \%$ to the commercial feed mixture.

Table 2. Composition of natural humic substances.

\begin{tabular}{lcr}
\hline Humic acids in dry matter & $\%$ & min. 65 \\
Free humic acids in dry matter & $\%$ & $\min .60$ \\
Fulvic acids & $\%$ & $\min .5$ \\
$\mathrm{Ca}$ & $\mathrm{mg} / \mathrm{kg}$ & 42278 \\
$\mathrm{Mg}$ & $\mathrm{mg} / \mathrm{kg}$ & 5111 \\
$\mathrm{Fe}$ & $\mathrm{mg} / \mathrm{kg}$ & 19046 \\
$\mathrm{Cu}$ & $\mathrm{mg} / \mathrm{kg}$ & 15 \\
$\mathrm{Zn}$ & $\mathrm{mg} / \mathrm{kg}$ & 37 \\
$\mathrm{Mn}$ & $\mathrm{mg} / \mathrm{kg}$ & 142 \\
$\mathrm{Co}$ & $\mathrm{mg} / \mathrm{kg}$ & 1.24 \\
$\mathrm{Se}$ & $\mathrm{mg} / \mathrm{kg}$ & 1.67 \\
$\mathrm{~V}$ & $\mathrm{mg} / \mathrm{kg}$ & 42.1 \\
$\mathrm{Mo}$ & $\mathrm{mg} / \mathrm{kg}$ & 2.7 \\
\hline
\end{tabular}

$\mathrm{Ca}$ - calcium, $\mathrm{Mg}$ - magnesium, $\mathrm{Fe}$ - ferrum, $\mathrm{Cu}$ - cuprum, $\mathrm{Zn}$ - zinc, $\mathrm{Mn}$ - manganese, $\mathrm{Co}$ - cobalt, $\mathrm{Se}$ - selenium, V-vanadium, Mo - molybdenum

The body weight of the individual broiler chicks was measured at weekly intervals and the feed consumption was recorded each day. The feed conversion ratio was calculated on the basis of feed intake to body weight gain. After the completion of the fattening period (day 35), the animals were weighed, stunned, killed by cervical dislocation and bled. The carcasses were plucked, eviscerated (removal of lungs and the gastrointestinal tract), and weighed. The carcass yield was determined as a proportion of the body weight before slaughter and after evisceration. The yields of breast meat (without bones) and thighs (with bones) were calculated as a proportion of meat weight and carcass weight. The results were expressed as a percentage of the body parts to the entire carcass.

Blood samples were collected from vena jugularis from fifteen birds in each group on the last day of fattening, using disposable sterile syringes. The blood was then transferred to sterilized centrifuge tubes. Total cholesterol, lipids and triglyceride levels were determined from blood serum by a method described by Tietz (1995). For HDL-cholesterol determination, a method described by Sugiuchi et al. (1995) was used. Concentration of LDL-cholesterol was determined by a method according to Bachorik (1997). The amount of HDL-cholesterol was enzymatically determined with cholesterol esterase and cholesterol oxidase. Determination of aspartate aminotransferase (AST), alkaline phosphatase (ALP), alanine transaminase (ALT), calcium and phosphorus was based on the absorbance measurement. The concentration of these enzymes and minerals was determined spectrophotometrically (Tietz 1995). For all spectrophotometric methods, Cobas C111 biochemistry analyzer (Roche diagnostics Ltd., Basel, Switzerland) was used. To determine the bone mineral profile, 12 pieces of broiler tibia bone (4 for each replicate) from each group were used. The analysis was conducted according to Onyango et al. (2003). Calcium was determined by flame atomic absorption spectroscopy at $422.7 \mathrm{~nm}$ (Perkin Elmer AAnalyst 100, PerkinElmer Inc., Waltham, USA). Total phosphorus in the samples was determined by the colorimetric method using ammonium molybdate at $620 \mathrm{~nm}$ (Spekord 210 Plus, Analytik Jena AG, Jena, Germany).

The data obtained from this experiment were evaluated using GraphPad Prism 3.0 and expressed as mean \pm standard deviation $(X \pm S D)$. Individual results between groups were statistically compared with one-way ANOVA test. Tukey comparison test was used to compare the differences between the values of the monitored groups and $P<0.05$ was considered a significant difference.

\section{Results}

The body weight and body weight gain of broilers at the end of fattening are presented in Table 3. Both experimental groups showed a non-significant increase in the body weight and weight gain, in comparison to the control group of broilers $(P>0.05)$. The highest mean body weight was recorded in the experimental group H1.0. The feed consumption was similar in all groups during the fattening $(P>0.05)$ but there was an improvement in the feed conversion ratio, especially for the group fed with $1.0 \%$ addition of HS (Table 3 ).

The means for carcass yield and yield of breast and thigh meats are shown in Table 4. No significant differences were recorded in the carcass yield $(P>0.05)$ but there was a significant increase in the yields of breast and thigh meats of broilers from experimental group H1.0 in comparison to that of the control group $(P<0.05)$.

The results of determination of selected blood enzymes and minerals are recorded in Table 5. A significant decrease in AST and increase in ALT were recorded in the experimental 
Table 3. The effect of adding humic substances to diet on the growth performance of 35-day-old broilers.

\begin{tabular}{lccc}
\hline & $\mathrm{C}$ & $\mathrm{H} 0.8$ & H1.0 \\
\hline Body weight gain $(\mathrm{g})$ & $2053.6 \pm 113.4$ & $2065.3 \pm 98.1$ & $2085.6 \pm 87.6$ \\
Body weight $(\mathrm{g})$ & $2101.8 \pm 117.3$ & $2113.5 \pm 102.0$ & $2133.8 \pm 99.5$ \\
Feed consumption $(\mathrm{g})$ & $3300.0 \pm 20.6$ & $3297.2 \pm 18.7$ & $3299.5 \pm 18.9$ \\
Feed conversion ratio & $1.61 \pm 0.20$ & $1.60 \pm 0.20$ & $1.58 \pm 0.20$ \\
\hline
\end{tabular}

$\mathrm{C}$ - control group of broilers, H0.8 - group of broilers fed with $0.8 \%$ humic substances addition, H1.0 - group of broilers fed with $1.0 \%$ humic substances addition

Table 4. Carcass characteristics (\%).

\begin{tabular}{llcl}
\hline & \multicolumn{1}{c}{$\mathrm{C}$} & H 0.8 & H 1.0 \\
\hline Carcass yield & $75.78 \pm 0.41$ & $75.94 \pm 0.39$ & $76.08 \pm 0.38$ \\
Breast meat yield & $26.20 \pm 0.61^{\mathrm{b}}$ & $26.38 \pm 0.45^{\mathrm{b}}$ & $27.68 \pm 0.41^{\mathrm{a}}$ \\
Thigh meat yield & $26.97 \pm 0.72^{\mathrm{b}}$ & $27.35 \pm 0.51^{\mathrm{ab}}$ & $28.59 \pm 0.63^{\mathrm{a}}$
\end{tabular}

$\mathrm{C}$ - control group of broilers fed with commercial feed, H0.8 - experimental group fed with $0.8 \%$ addition of humic substances, H1.0 - experimental group of broilers fed with $1 \%$ addition of humic substances to commercial feed, a,b - values with different superscripts in a row are significantly different at $P<0.05$, mean $\pm \mathrm{SD}$ (standard deviation), $\mathrm{n}=24$

Table 5. Determination of blood enzymes and minerals in blood of broilers.

\begin{tabular}{lccc}
\hline Metabolites & $\mathrm{C} \pm \mathrm{SD}$ & $\mathrm{H} 0.8 \pm \mathrm{SD}$ & $\mathrm{H} 1.0 \pm \mathrm{SD}$ \\
\hline AST $(\mu \mathrm{kat} /)$ & $5.11 \pm 0.48^{\mathrm{a}}$ & $4.14 \pm 0.86^{\mathrm{b}}$ & $4.79 \pm 0.83^{\mathrm{ab}}$ \\
ALT $(\mu \mathrm{kat} / \mathrm{l})$ & $0.03 \pm 0.02^{\mathrm{b}}$ & $0.06 \pm 0.02^{\mathrm{a}}$ & $0.04 \pm 0.02^{\mathrm{b}}$ \\
ALP $(\mu \mathrm{kat} /)$ & $75.73 \pm 20.04^{\mathrm{a}}$ & $66.93 \pm 17.45^{\mathrm{a}}$ & $43.25 \pm 14.33^{\mathrm{b}}$ \\
GMT $(\mu \mathrm{kat} / \mathrm{l})$ & $0.33 \pm 0.06$ & $0.35 \pm 0.08$ & $0.33 \pm 0.08$ \\
$\mathrm{CHOL}(\mathrm{mmol} / \mathrm{l})$ & $3.48 \pm 0.44^{\mathrm{a}}$ & $3.24 \pm 0.40^{\mathrm{b}}$ & $3.17 \pm 0.29^{\mathrm{b}}$ \\
TG $(\mathrm{mmol} /)$ & $0.84 \pm 0.26$ & $0.79 \pm 0.28$ & $1.08 \pm 0.35$ \\
TL $(\mathrm{g} / \mathrm{l})$ & $5.11 \pm 0.54^{\mathrm{b}}$ & $5.75 \pm 0.83^{\mathrm{ab}}$ & $6.93 \pm 0.67^{\mathrm{a}}$ \\
HDL $(\mathrm{mmol} /)$ & $2.33 \pm 0.10$ & $2.43 \pm 0.14$ \\
LDL $(\mathrm{mmol} / \mathrm{l})$ & $2.39 \pm 0,32$ & $0.91 \pm 0.26$ & $0.84 \pm 0.03$ \\
\hline Minerals & $0.73 \pm 0.16$ & & $3.23 \pm 0.10^{\mathrm{ab}}$ \\
\hline $\mathrm{Ca}(\mathrm{mmol} / \mathrm{l})$ & & $2.90 \pm 0.46^{\mathrm{b}}$ & $3.33 \pm 0.10$ \\
P (mmol/) & $3.26 \pm 0.43^{\mathrm{a}}$ & $2.98 \pm 0.25$ & $0.85 \pm 0.04$ \\
$\mathrm{Mg}(\mathrm{mmol} /)$ & $3.37 \pm 1.22$ & $0.81 \pm 0.05$ & \\
\hline
\end{tabular}

$\mathrm{C}$ - control group of broilers fed with commercial feed, H0.8 - experimental group fed with $0.8 \%$ addition of humic substances, H1.0 - experimental group of broilers fed with 1\% addition of humic substances to commercial feed, AST - aspartate aminotransferase, ALT - alanine aminotransferase, ALP - alkaline phosphatase, GMT - gamma-glutamyltransferase, CHOL - cholesterol, TG - triglycerides, TL - total lipids, $\mathrm{HDL}$ - high density lipoprotein, LDL - low density lipoprotein, $\mathrm{Ca}$ - calcium, $\mathrm{P}$ - phosphorus, $\mathrm{Mg}$ - magnesium, a,b - values with different superscripts in a row are significantly different at $P<0.05$, mean \pm SD (standard deviation), $\mathrm{n}=15$

group H0.8, whereas the obtained value for ALP was significantly lower in group H1.0. The amount of total lipids (TL) was increased in both experimental groups but considerably higher in group H1.0 $(P<0.05)$. The serum cholesterol level was lower in broilers of both experimental groups $(P<0.05)$. 
Table 6. Mineral profile of bones $(\mathrm{mg} / \mathrm{kg})$.

\begin{tabular}{lrrr}
\hline Mineral & \multicolumn{1}{c}{$\mathrm{C}$} & H0.8 & \multicolumn{1}{c}{ H1.0 } \\
\hline $\mathrm{Ca}(\mathrm{mg} / \mathrm{kg})$ & $218606 \pm 19538^{\mathrm{b}}$ & $249888 \pm 4047^{\mathrm{a}}$ & $254444 \pm 3997^{\mathrm{a}}$ \\
$\mathrm{P}(\mathrm{mg} / \mathrm{kg})$ & $14873 \pm 1226^{\mathrm{a}}$ & $9845 \pm 1247^{\mathrm{b}}$ & $10748 \pm 1083^{\mathrm{b}}$ \\
\hline
\end{tabular}

$\mathrm{C}$ - control group of broilers fed a commercial feed, $\mathrm{H} 0.8$ - experimental group fed with $0.8 \%$ addition of humic substances, H1.0 - experimental group of broilers fed with $1 \%$ addition of humic substances to a commercial feed, $\mathrm{Ca}$ - calcium, $\mathrm{P}$ - phospohorus, ${ }^{\mathrm{a}, \mathrm{b}}$ - values with different superscripts in a row are significantly different at $P<0.05$, mean $\pm \mathrm{SD}$ (standard deviation), $\mathrm{n}=12$

The effect of HS addition was evident in the mineral composition of bones (Table 6). A significant increase in calcium and a decrease in phosphorus contents were found in the bones of broilers fed with HS addition $(P<0.05)$.

\section{Discussion}

Humic substances are considered to be a suitable alternative to antibiotic growth promoters in broiler diets. They can be administered in the feed (Eren et al. 2000; Ozturk et al. 2012) or in drinking water at various concentrations (Ozturk et al. 2010).

Better growth parameters, greater feed efficiency and minor mortality have been recorded in broilers fed with the addition of this organic and nontoxic matter (Eren et al. 2000; Karaoglu et al. 2004; Ozturk et al. 2012). In contrast, some studies showed a non-significant effect on the broilers during the fattening period (Kaya and Tuncer 2009; Nagaraju et al. 2014). Thus, the objective of this study was to observe the effect of feeding with $0.8 \%$ and $1.0 \%$ addition of the HS to broilers feed.

The results of the presented study reveal that feeding with dietary HS at concentrations of $0.8 \%$ and $1 \%$ had a tendency to cause an increase in the body weight and weight gain $(P>0.05)$. These particular concentrations of HS were selected according to the producer's recommendations) and information obtained from previous experiments. The higher HS addition $(1 \%)$ showed a slightly stronger effect on growth parameters $(P>0.05)$. This positive impact was more pronounced in balanced values on the chicken body weight and lower variance of SD in experimental group H1.0. This finding is similar to the conclusion made by Pistová et al. (2016) who reported that broiler chickens fed a diet containing 1\% of humic acid showed a significantly higher body weight $(P<0.05)$ in comparison to the control. Furthermore, other studies reported an increase in body weight especially during the last stage of fattening (Karaoglu et al. 2004; Ozturk et al. 2012; Salah et al. 2015). According to Arif et al. (2018), the HS forms a protective film on the mucous epithelia of the gastrointestinal tract against infectious/pathogenic agents and toxins, which results in an increased weight gain and final weight of animals.

An improved feed conversion ratio was observed at the end of fattening in both experimental groups. The result is consistent with the findings reported by Avci et al. (2007), Prayogi (2011) and Bahadori et al. (2017). This could be explained by the fact that humic acids stabilise the intestinal microflora, therefore ensuring better utilisation of nutrients from feed (Avci et al. 2007). In contrast, Kaya and Tuncer (2009) observed no improvement in the feed conversion ratio. Only a non-significant increase was recorded in carcass weights in their study, whereas a significant increase in the yield of breast and thigh meats from chickens fed diets enhanced with HS was noted in our experiment. The same results were presented by Arif et al. (2018) and Aksu and Bozkurt (2009) who also found increased weights after supplementation of HS in diet. 
One of the objectives of this study was to evaluate selected blood parameters of broilers fed diets supplemented with HS. The blood enzymes AST and ALT serve as indicators of liver damage. Both tested concentrations of HS confirmed a positive effect on the reduction of AST and ALP in the blood of broilers from the experimental groups. A significantly higher level of ALT was recorded in group HS0.8 compared to the control group. However, this value was still within the reference range of ALT levels for poultry. Based on our results, we can confirm the positive impact of $1.0 \%$ HS feed addition on the reduction of ALP and AST levels in the blood of broilers. Similar findings were presented by Rath et al. (2006). The authors also recorded a decrease in the concentrations of ALP and AST in the blood of broilers fed with a $1.0 \%$ and $1.25 \% \mathrm{HS}$ feed addition. On the other hand, no significant decrease of AST and ALP after feeding with HS was found by Šamudovská and Demeterová (2010), however, it is important to consider that the concentration of added HS was lower $(0.5 \%)$ in their experiment.

A well-known beneficial effect of feeding with added HS is a decrease in the blood plasma cholesterol concentrations (Ozturk et al. 2012). Bahodari et al. (2017) also observed decreased concentrations of cholesterol after feeding broiler chickens a diet containing HS. These results are in agreement with our findings, as we recorded a decrease in blood cholesterol in both experimental groups of broilers. Reduction of blood cholesterol could be affected by a decrease in the intracellular $\mathrm{pH}$ (Arif et al. 2018).

Calcium and phosphorus are essential macroelements for bones, as well as for energy metabolism. The supplementation of HS at a $0.8 \%$ concentration in our experiment was associated with a decrease both in blood calcium $(P<0.05)$ and in phosphorus. The same findings were presented in a study by Rath et al. (2006) who reported a decrease both in blood calcium and in phosphorus after the addition of HS to broiler feed. Conversely, Bahodari et al. (2017) and Ozturk et al. (2012) observed an increase in blood calcium and phosphorus. On the other hand, Arif et al. (2018) observed no changes in the levels of these blood elements in quails. The effect of HS on the concentration of calcium and phosphorus in blood can be affected by the amount added to the feed. The addition of HS at a $1.0 \%$ concentration did not significantly affect the concentration of calcium and phosphorus in blood.

The reduction of serum concentration of calcium and phosphorus may be caused by the ability of HS to chelate metals, which is affected by a large number of carboxylic acid side-chains (Rath et al. 2006). A possible explanation for the lower content of calcium in blood could be that there is a greater accumulation of this element in the bones of both experimental groups. Thus, the addition of HS in the feed was reflected by a higher amount of calcium detected in the tibiae. The effect of addition of HS was evident in the mineral composition of bones. There was a significant increase in the calcium content in bones of broilers fed with HS $(P<0.05)$. This could be attributed to the ability of HS to increase the degree of mineralisation of the bone matrix (Nkukwana et al. 2014; Disetlhe et al. 2017). On the contrary, Yildiz et al. (2013) reported no effect of HS on bone characteristics and calcium level. Generally, insufficient dietary sources of calcium can result in blood hypocalcaemia, which may lead to reduced bone strength and reduced mineralization. Calcium and phosphorus play an intrinsic role in the structure and metabolism of bone.

In conclusion, we can state that feeding with HS $(0.8 \%$ and $1.0 \%)$ manifested as an improvement in the final body weight of broilers and in the feed conversion ratio. There was a significant effect on the blood cholesterol level and the contents of calcium and phosphorus in the bones of broilers. Comparing both concentrations, the $1 \%$ addition showed a more pronounced effect. After the addition of the higher concentration of HS in feed, a decrease in AST and ALP, a higher level of total lipids in blood, and a higher yield of breast and thigh meats were recorded. 


\section{Acknowledgements}

This work was supported by the Ministry of Education, Science, Research and Sport of the Slovak Republic under the project VEGA No. 1/0408/17.

\section{References}

Aksu T, Bozkurt AS 2009: Effect of dietary essential oils and/or humic acids on broiler performance, microbial population of intestinal content and antibody titres in the summer season. Kafkas Univ Vet Fak Derg 15: 185-190

Arafat RY, Khan SA, Saima I 2017: Evaluation of humic acid as an aflatoxin binder in broiler chickens. Ann Anim Sci 17: 241-255

Arif M, Rehman A, El-Hack MEA, Saeed M, Khan F, Akhtar M, Swelum AA, Saadeldin IM, Alowaimer AN 2018: Growth, carcass traits, cecal microbial counts, and blood chemistry of meat-type quail fed diets supplemented with humic acid and black cumin seeds. Asian-Aust J Anim Sci 31: 1930-1938

Avci M, Denek N, Kaplan O 2007: Effects of humic acid at different levels on growth performance, carcass yields and some biochemical parameters of quails. J Anim Vet Adv 6: 1-4

Bachorik PS 1997: Measurement of low-density lipoprotein cholesterol. Handbook of lipoprotein testing, AACC Press, Washington.

Bahadori Z, Esmaielzadeh L, Karimi-Torshizi MA, Seidavi A, Olivares J, Rojas S, Salem AZM, Khusro A, López S 2017: The effect of earthworm (Eisenia foetida) meal with vermi-humus on growth performance, hematology, immunity, intestinal microbiota, carcass characteristics, and meat quality of broiler chickens. Livest Sci 202: 74-81

COBB Broiler Management Guide 2013: COBB Broiler Management Guide, cobb-vantress.com, L-1020-05, November 15, 2013, 68 p.

Disetlhe ARP, Marume U, Mlambo V, Dinev I 2017: Humic acid and enzymes in canola-based broiler diets: Effects on bone development, intestinal histomorphology and immune development. S Afr J Anim Sci 47: 914-922

Eren M, Deni G, Gezen ȘȘ, Türkmen III 2000: Effects of humates supplemented to the broiler feeds on fattening performance, serum mineral concentration and bone ash. Ankara Univ Vet Fak 47: 255-263

Karaoglu M, Macit M, Esenbuga N, Durdag H, Turgut L, Bilgin ÖC 2004: Effect of supplemental humate at different levels on the growth performance, slaughter and carcass traits of broilers. Int J Poult Sci 3: 406-410

Kaya CA, Tuncer SD 2009: The effects of humates on fattening performance, carcass quality and some blood parameters of broilers. J Anim Vet Adv 8: 281-284

Khan SH, Iqbal J 2016: Recent advances in the role of organic acids in poultry nutrition. J Appl Anim Res 44: 359-369

Nagaraju R, Reddy BS, Gloridoss R, Suresh BN, Ramesh C 2014: Effect of dietary supplementation of humic acids on performance of broilers. Indian J Anim Sci 84: 447-452

Nkukwana TT, Muchenje V, Masika PJ, Hoffman LC, Dzama K 2014: The effect of Moringa oleifera leaf meal supplementation on tibia strength, morphology and inorganic content of broiler chickens. S Afr J Anim Sci 44: 228-239

Onyango EM, Hester PY, Stroshine R, Adeola O 2003: Bone densitometry as an indicator of percentage tibia ash in broiler chicks fed varying dietary calcium and phosphorus levels. Poultry Sci 82: 1787-1791

Ozturk E, Ocak N, Coskun I, Turhan S, Erener G 2010: Effects of humic substances supplementation provided through drinking water on performance, carcass traits and meat quality of broilers. J Anim Physiol Anim Nutr 94: $78-85$

Ozturk E, Ocak N, Turan A, Erener G, Altop A, Cankaya S 2012: Performance, carcass, gastrointestinal tract and meat quality traits, and selected blood parameters of broilers fed diets supplemented with humic substances. J Sci Food Agric 92: 59-65

Pistová V, Arpášová H, Hrnčár C 2016: The effect of the humic acid and garlic (Allium sativum L.) on performance parameters and carcass characteristic of broiler chicken. J Cent Eur Agric 17: 1168-1178

Prayogi HS 2011: The effect of earthworm meal supplementation in the diet on quail's growth performance in attempt to replace the usage of fish meal. Int J Poult Sci 10: 804-806

Rath NC, Huff E, Wand Huff GR 2006: Effects of humic acid on broiler chickens. Poult Sci 85: 410-414

Salah H, Masour ES, Reham RR, El Hamid ESA 2015: Study on the effect of humic acid on growth performance, immunological, some blood parameters and control intestinal closterdium in broiler chickens. Zag Vet J 43: 102-109

Šamudovská A, Demeterová M 2010: Effect of diet supplemented with natural humic compounds and sodium humate on performance and selected metabolic variables in broiler chickens. Acta Vet Brno 79: 385-393

Sugiuchi H, Uji Y, Okabe H, Irie T, Uekama K, Kayahara N, Miyauchi K 1995: Direct measurement of high-density lipoprotein cholesterol in serum with polyethylene glycol-modified enzymes and sulfated alpha-cyclodextrin. Clin Chem 41: 717-723

Tietz NW 1995: Clinical guide to laboratory tests, ( $3^{\text {rd }}$ edn) WB Saunders Company: Philadelphia.

Yıldız G, Köksal BH, Sizmaz Ö 2013: Influence of dietary boric acid and liquid humate inclusion on bone characteristics, growth performance and carcass traits in broiler chickens. Arch Geflügelk 77: 260-265 